\title{
Influence of Strategic Practices on Corporate Governance in Selected Kenyan Parastatals
}

\author{
Jennifer Kalekye Mbondo ${ }^{1}$, Dr. Assumptah Kagiri ${ }^{2}$ \\ ${ }^{1}$ MBA, Jomo Kenyatta University of Agriculture and Technology, P.O Box 620000 - 00200 Nairobi, Kenya \\ ${ }^{2}$ Supervisor, Jomo Kenyatta University of Agriculture and Technology
}

\begin{abstract}
Recent and continuous global events involving major corporate and business failures continue to reverberate the importance of good corporate governance as a catch phrase necessary for ensuring the financial health and viability of business entities so that the interests of all stakeholders are protected and to prevent the unfair dominance of the interests of any stakeholder over those of the others. The general objective of the current study was to assess the influence of strategic practices on corporate governance in Kenyan parastatals. The study was guided by four objectives: To determine the effect of board composition as a strategic practice on corporate governance in Kenyan parastatals. To establish the effect of accountability on corporate governance in Kenyan parastatals. To determine the effect of ethical practices on corporate governance of parastatals in Kenya. To assess the influence corporate social responsibility has on corporate governance in Kenyan parastatals. The study was guided by several theories including the: Agency Theory, Stewardship Theory, Stakeholders Theory Political Theory, and Resource Dependency Theory. The study adopted a descriptive research design. The entire 46 parastatals formed the target population for the study Stratified random sampling were used to pick the parastatals that were to be considered for the study. 14 parastatals from the Class A were considered for the study and 292 Respondents formed the sample size. The primary data was collected by use of a structured questionnaire using the Likert Scale. Split-Half technique of reliability testing was employed in the study whereby the pilot questionnaires were divided into two equivalent halves and then a correlation coefficient for the two halves computed using the Spearman Correlation Formula. Data was analyzed using both quantitative and qualitative methods. The results of data analysis were presented using frequency distribution tables and bar graphs this facilitated description and explanation of the information. The study concluded the variables collectively have a significant effect on corporate governance in Kenyan parastatals, it's evident from the table that $87.9 \%$ of variation or change in the corporate governance is explained by; board composition, accountability, ethical practices, and corporate social responsibility. This implies that these factors are very significant (since the p-values $<0.05$ ) and therefore need to be considered as a strategy in implementation of corporate governance. The study found out that good corporate governance is a vital element to firm performance. The study established that, generally, there is a positive relationship between corporate governance and the board composition, accountability, ethical practices and corporate social responsibility in selected Kenyan parastatals.
\end{abstract}

Keywords: Corporate Governance, Board Composition, Accountability, Business Ethics, Corporate Social Responsibility

\section{Introduction}

Corporate governance has been the major theme making headline in business over the past two decades. Major accounting failures at Enron and other corporations have dented investors' confidence and raised more questions on managerial ethics, efficiency and effectiveness of company internal controls and governance. Thus, it implies that corporate governance mechanisms are enhanced and enforced in order to mitigate the business anomalies. The critical areas addressed by corporate governance can be easily described as, efficient, responsible, transparent and honest governance of economic entities, whether they are private or state owned, large, medium or small. The principles set out by the Commonwealth Association for Corporate Governance (CACG) are a well-recognized benchmark within the Commonwealth; but similar codes and principles, for example the Cadbury and King Reports, are available in other jurisdictions.

In Kenya, the campaign for good corporate governance has been led by regulatory authorities such as the Capital Market Authority (CMA), the Nairobi Security Exchange (NSE) formerly the Nairobi Stock Exchange, and the Central Bank of Kenya (CBK). Corporations and institutional investors, as well as shareholders have also stressed good corporate governance practices and have developed or issued guidelines to enhance good governance and corporate responsibility in running the affairs of various corporate bodies. Consequently, the International Monetary Fund has stressed good corporate as one of the requirements of debt relief for nations needing the fund's assistant. Performance of the parastatals has been a matter of on-going concern in an environment of resource scarcity and mounting needs. Kenya has not been exempted from corporate collapses over the past years. It bears to remind that in the 80s more than 33 banks collapsed and other parastatals such as Kenya Cooperative Creameries (KCC), National Housing Corporation (NHC) etc,and few followed suit in the past decade. The critical policy issues and challenges afflicting parastatals in Kenya, including: poor governance leading to resource loss and burdening the public purse, multitude of legal and institutional frameworks that generate multiple reporting and accountability lines, compounding the challenge of effectiveness of Boards and Chief Executive Officers, and lack of clarity on the role that parastatals should play in the economy. This is compounded by the apparent differences in opinion in respect of the exact role of the state in the national development effort and Poor linkage of Parastatals activity with the national development goal and the external stakeholders. The corporate governance in parastatals is thus developed on the framework of balancing the interests of the variety of key groups such as employees, managers, creditors, suppliers, customers and community (Solomon \& Solomon, 2004). 


\section{International Journal of Science and Research (IJSR) \\ ISSN (Online): 2319-7064}

Index Copernicus Value (2013): 6.14 | Impact Factor (2015): 6.391

\subsection{Specific Objectives}

1) To determine the effect of board composition as a strategic practice on corporate governance in selected Kenyan parastatals.

2) To establish the effect of accountability on corporate governance in selected Kenyan parastatals.

3) To determine the effect of ethical practices on corporate governance of selected parastatals in Kenya.

4) To assess the influence corporate social responsibility has on corporate governance in selected Kenyan parastatals.

\section{Theoretical Review}

\subsection{Agency Theory}

Agency theory is defined as the relationship between the principals, such as shareholders and agents such as the company executives and managers. In this theory, shareholders who are the owners or principals of the company, hires the agents to perform work. Principals delegate the running of business to the directors or managers, who are the shareholder's agents (Clarke, 2004). Agency theory suggests that managers in organizations can be self-interested. The agency theory shareholders expect the agents to act and make decisions in the principal's interest. On the contrary, the agent may not necessarily make decisions in the best interests of the principals (Padilla, 2000). The agent may be driven to self-interest, opportunistic behavior and falling short of congruence between the aspirations of the principal and the agent's pursuits. Even the understanding of risk defers in its approach. Although with such setbacks, agency theory was introduced basically as a separation of ownership and control (Bhimani, 2008).

\subsection{Stewardship Theory}

A steward is defined by Davis, Schoorman and Donaldson (1997), as one who protects and maximizes shareholders wealth through firm performance, because by so doing, the steward's utility functions are maximized. In this perspective, stewards are company executives and managers working for the shareholders, protects and make profits for the shareholders. Stewardship theory stresses not on the perspective of individualism, but rather on the role of top management being as stewards, integrating their goals as part of the organization. Stewardship theory offers an alternative to agency theory by suggesting that when a convergence of values exists between principals and agents or when organizations promote unselfish values, responsible behavior results by internal means (Dicke, 2000). Lack of trust referred to by the agency theory regarding authority and ethical behavior is what is replaced by this theory which is one of the key distinguishing features of it.

\subsection{Stakeholders Theory}

Wheeler et al, (2002) argued that stakeholder theory was derived from a combination of the sociological and organizational disciplines. Stakeholder theory can be defined as any group or individual who can affect or is affected by the achievement of the organization's objectives. Stakeholder theorists suggest that managers in organizations have a network of relationships to serve - this include the suppliers, employees and business partners.According to Freeman et al. (2004), stakeholder theory basically aims at striking a balance between the interests of a corporation's stakeholders and their satisfaction. It tries to identify the purpose of the firm. Identification of the firm's purpose therefore becomes the driving force underlying its activities (Freeman et al., 2004).

\section{Conceptual Framework}

The conceptual framework of this study outlines the dependent and the independent variables as discussed in the literature review. It helps one to understand the relationship between the variables of the study.

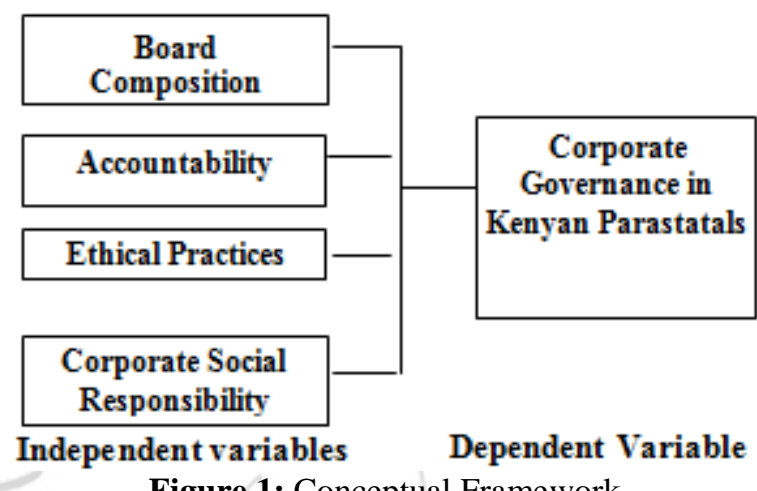

\subsection{Research Gap}

Much of literature quoted relates to research work done on firms operating in developed Western countries. There is a conspicuous lack of literature relating to corporate governance on the African continent and especially within the Kenyan context. Information relating to governance of Kenyan is scanty. Widely available information relating to corporate governance is made up of newspaper articles and annual reports and accounts published by public companies. Thus, It is necessary to investigate and report on the impact of strategic practices on corporate governance in Kenyan parastatals.

\section{Research Design, Data Analysis and Processing}

\subsection{Data Analysis}

The study adopted a descriptive research design in investigating the relationship between corporate governance and strategic practices of parastatals in Kenya. Descriptive research design allows the researcher to study the elements in their natural form without making any alterations to them. Both qualitative and quantitative primary data was used for the study. The primary data was collected by use of a structured questionnaire using the Likert Scale. The Statistical Package for Social Sciences (SPSS version 20) was used to run descriptive statistics such as means and standard deviations based on the major research questions. Inferential statistics which included Pearson correlation and 


\section{International Journal of Science and Research (IJSR) \\ ISSN (Online): 2319-7064}

Index Copernicus Value (2013): 6.14 | Impact Factor (2015): 6.391

Multi linear regression analysis were used to establish the relationship among the study variables.

\subsection{Data Presentation}

The results of data analysis were presented using frequency distribution tables and bar graphs. This facilitated description and explanation of the information. The qualitative data generated from open ended questions was analyzed by use of content analysis.

\section{Research Findings and Discussion}

\subsection{Response Rate}

The target population was 292 respondents The questionnaires were delivered by the researcher and filled and the return rate was $75.68 \%$ which was 221 questionnaires.

Mugenda and Mugenda (2003) observes that a 50\% response rate is adequate, $60 \%$ good and above, while $70 \%$ rated very well. This implies that based on this assertion, the response rate in this case of $80.89 \%$ was therefore very good.

\subsection{Board Composition}

The study sought assess the influence of strategic practices on corporate governance in selected Kenyan parastatals and thus four variables are studied to assess their influence including, the board composition, Accountability, ethical practices and corporate social responsibility.

The respondents strongly agreed that the Chairman is a separate person from the CEO with a mean of 4.82 and with a mean of 4.93 strongly agreed there is an established clear job description for the board chair and members which is different from those of the CEO and management. The respondents disagreed with a mean of 2.02 and standard deviation of 0.408 that separating the roles of CEO and Chairman of the board (COB) potentially leads to confusion and lack of clarity, both internally with employees and externally with other stakeholders however with a mean of 4.880 and standard deviation of 0.448 that separating the $\mathrm{CEO}$ and $\mathrm{COB}$ roles does not necessarily guarantee a strong monitoring function if the collective board is otherwise weak.

\subsection{Accountability}

The respondents agreed with the position that there are appropriate policies and procedures to identify and deal with any potential conflicts of interest with a mean of 4.07 and a standard deviation of 0.457 , there is disclosure of the biographies of the board of directors and senior management with a mean of 4.12 and standard deviation of 0.324 . However the respondents disagreed there is disclosure of board and senior management compensation with a mean of 1.91 and standard deviation of 0.526 . The respondents disagreed with the statement the board and the management of the parastatals have set up various controls to ensure accountability with a mean of 2.93 and standard deviation of
0.258. The findings are similar to Meyers (2008), accountability begins with the CEO and boards of directors.

\subsection{Ethical Practices}

The respondents strongly agreed there is promotion of effective participation of all board members in the decisionmaking process with a mean of 4.77 and standard deviation of 0.527; Transparency is among the core values of the organization with a mean of 4.02 and standard deviation of 0.266 procedures are put in place to ensure that ethical behavior is upheld in the organization with a mean of 4.88 and standard deviation of 0.448 . However the respondents were neutral on whether there is a clear distinction of decisions made by the board and decisions made by the management with a mean of 3.07 and standard deviation of 0.258 and there exist structures that exist to cater for unethical practices with a mean of 3.23 and standard deviation of 0.649 . The respondents disagreed with the statement the board has adopted appropriate decision making processes with a mean of 2.02 and standard deviation of 0.408 .

The issue of ethics is key in ensuring corporate governance as highlighted by the findings and agrees with previous studies that since the beginning of the 21 st century, serious financial scandals and many cases of corporate mismanagement brought about an increasing attention to corporate governance, in a close relation with business ethics issues (Sanda et al., 2005).

\subsection{Corporate Social Responsibility}

The respondents were of the opinion that CSR performance has a lot of value to the corporation in the form of acting as an insurance policy against financial scandals and the drop of investor's confidence. However, as the parastatals increase their adoption of CSR performance, managers are under pressure to justify the allocation of scarce firms' resources and also provide accurate measurement of CSR performance and that they lack strategic management practices and ability to select CSR projects. The respondents were of the opinion there seems to be no links between strategic management practices and CSR performance

\section{Conclusion}

Pearson correlation was used to measure the degree of association between independent and dependent variables. The analysis showedthat ethical practice has the strongest positive influence on corporate governance. A regression coefficient of 1.078 implies that a unit change in ethical practice increases the corporate governance in selected Kenyan parastatals by $107.8 \%$. In testing the significance of board composition in the relationship, it implies a strong relationship with a regression coefficient of 0.050 , thus a unit of board composition results to $5 \%$ changes in corporate governance in selected Kenyan parastatals. Accountability also showed a strong positive relationship with a regression coefficient of 0.243 . Aunit of accountability results to $24.3 \%$ changes in corporate governance in selected Kenyan parastatals.A regression coefficient of 0.054implies that a 


\section{International Journal of Science and Research (IJSR) \\ ISSN (Online): 2319-7064}

Index Copernicus Value (2013): 6.14 | Impact Factor (2015): 6.391

unit of corporate social responsibility increases the corporate governance in selected Kenyan parastatals by $5.4 \%$.

The study established that, generally, there is a positive relationship between corporate governance and the identified independent variables in selected Kenyan parastatals and this concludes that good corporate governance is a vital element to firm performance.

\section{Recommendations}

As the study has revealed that that multiple directorship has positive and strong relationship to financial performance, the researcher recommends that only individuals with proven records of experience, innovation and with the capacity to galvanize resources are appointed to the board of the parastatals. Parastatals should also be very keen in the supervisory role through the relevant committees to ensure that all regulations are enforced as required e.g. books of accounts are well -kept and audited as they should be. Organization should come up with codes of conduct to guide employees in their day today business and how they should deal with ethical dilemmas whereby defying them would constitute a serious act of misconduct. Consequently, performance of CSR should be part of every parastatals long term action plan so that both the parastatal and the society benefits,

\section{Areas for Further Study}

There is a need for further studies to be conducted separately on each sector of the parastatals. That is, separate studies should be conducted exclusively on profit-oriented commercial parastatals, regulatory parastatals, public policy and social-service oriented parastatals to determine the impact of corporate governance on their performance. This would enable the government undertake a more comprehensive measure aimed at enhancing efficiency and productivity.

\section{References}

[1] Ahrens, T. (2008), "The hidden ethics of corporate governance and the practical uses of corporate governance codes: A commentary on Andre' R. (2010) Assessing the accountability of government-sponsored enterprises and quangos.Journal of Business Ethics 2010;97(2):271-89

[2] Anderson, T.J. (2000). Strategic Planning, Autonomous Actions and Corporate Performance. Long Range Planning.33 (2), 184-200.

[3] Azapagic, A. (2004). Developing a framework for sustainable development indicators for the mining and minerals industry. Journal of Cleaner Production. 12(6), 639-662.

[4] Baker, E. Godridge. (2007). Corporate Governance Ratings in Emerging Markets: Implications for Market Valuation, Internal Firm Performance, Dividend Payouts and Policy Paper presented at the International Research Conference on Corporate Governance.
[5] Bergman, B. \& Klefsjo, B. (2003). Quality from Customer Needs to Customer Satisfaction. (2nded.).Quality Management Book. Lund.20 (1), v-vi

[6] Bhimani, A. (2008), "Making corporate governance count: The fusion of ethics and economic rationality" ", Journal of Management \& Governance, Vol 12 No. 2, pp. 135-147.

[7] Bovens M.(2007) Analysing and assessing accountability: a conceptual framework. European Law Journal 2007;13(4):447-68.

[8] Bovens M.(2009) Public accountability. In: Ewan F, Lawrence Jr L, Pollitt C, editors. Oxford: Oxford Handbooks; 2009.

[9] Broadbent J, Dietrich M, Laughlin R. The development of principal-agent, contracting and accountability relationships in the public sector: conceptual and cultural problems. Critical Perspectives on Accounting 1996; 7(3):259-84.

[10] Burke, L. \& Logsdon, J.M. (2006). How Corporate Social Responsibility Pays Off. Long Range Planning. 29(4), 495-502.

[11] Cairnes M. (2003). Boardrooms That Work. A guide to Board Dynamics, Sydney.

[12] Campbell, J.L. (2007). Why would corporations behave in socially responsible ways? An institutional Theory of corporate social responsibility. Academy of Management Review. 32(3), 946-967.

[13] Commonwealth Association of Corporate Governance (1999).A guide to good corporate Governance Practice

[14] Clarke, P. (2007). International Corporate Governance: A comparative Approach. Oxon: Routledge.

[15] Gjolberg, M. (2009). Measuring the immeasurable? Constructing an index of CSR practices and CSR performance in 20 countries. Scandinavian Journal of Management.25 (1), 1022.

[16] Government of Australia (2003).ASX Corporate Council: principles of good Corporate

[17] Government of Kenya, (2012). State Corporation Act. Revised Edition

[18] Harford, J., Mansi, A., \& Maxwell, F. (2008). Corporate governance and firm cash holding in the US. Journal of Finance Economics 87(3)

[19] Hino, K. (2006). Corporate Social and Financial Performance: An Empirical Study on a Japanese company. Berlin. IFSAM VIIlth World congress.

[20] Kihumba, J. (1999). Corporate Governance is about Corporate Democracy. Journal of the Institute of Certified Public Secretaries of Kenya, June. 20, 1999

[21] Mang'unyi, E. (2011). Ownership structure and Corporate Governance and its effects on performance: A case of selected Banks in Kenya. International Journal of Business Administration.

[22] Miring'u, A and Muoria ET (2009). An analysis of the Effect of Corporate Governance on Performance of Commercial Parastatals in

[23] Mugenda, MG. (1999, Revised 2003). Research Methods: Quantitative and Qualitative Approaches. 2nded. Nairobi: Acts.

[24] Ogula, P. A. (2005). Research Methods. Nairobi: CUEA Publications.

[25] Orodho, A. J. (2003). Essentials of Educational and Social Sciences Research Method. Nairobi: Masola Publishers. 


\section{International Journal of Science and Research (IJSR) \\ ISSN (Online): 2319-7064}

Index Copernicus Value (2013): 6.14 | Impact Factor (2015): 6.391

[26] Owens, L. K. (2002). Introduction to Survey Research Design. SRL Fall 2002 Seminar Series. Retrieved September 20, 2015 from http://www.srl.uic.edu

[27] Padilla, A. (2002): Can Agency Theory Justify The Regulation Of Insider Trading. The Quarterly Journal of Austrian Economics.12 (4), 140-142

[28] Shleifer, A., and Vishny, R.W. (2007). A survey of Corporate Governance. Journal of Finance.

[29] Sirgy, M.J. (2002). Measuring corporate performance by building on the stakeholders model of business ethics. Journal of Business Ethics. 35(3), 143-162.

[30] Slater, S.F., Olson, E.M. \& Hult, G.T.M. (2006). The moderating influence of strategic orientation on the strategy formulation capability - Performance Relationship. Strategic Management Journal. 27(12), 1221-1231.

[31] White, A.L. (2009). Democratizing the Corporation, Humanism in Business. Cambridge. Cambridge University Press.

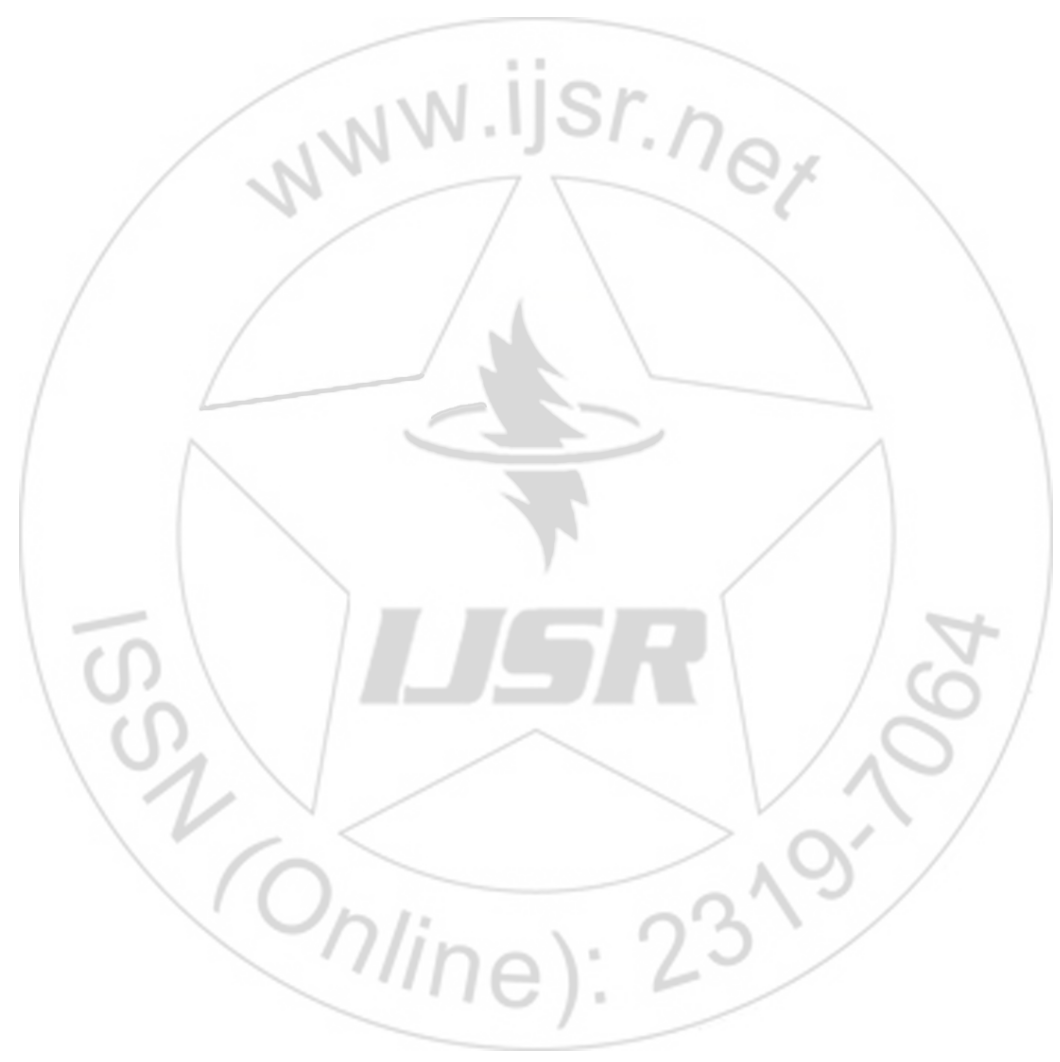

